\title{
A Democracia Contemporânea e os Sinais do seu Desgaste: um estudo com aportes na doutrina Luigi Ferrajoli para o delineamento de um possível caminho a seguir
}

\author{
The Contemporary Democracy and the Sign of its Erosion: a study with the \\ contribution of Luigi Ferrajoli doctrine outlining a possible way forward
}

\author{
Maurizio Oliviero \\ Pablo Franciano Steffen \\ Daniel Mayerle
}

Resumo: Este artigo apresenta uma breve abordagem sobre a crise da democracia contemporânea e a sua relação com o fenômeno da transnacionalidade, com o propósito de oferecer uma visão sintética, mas clara, dos principais fatores que tornam a democracia clássica insuficiente para dar respostas adequadas aos novos desafios engendrados pela sociedade global do século XXI. Para tanto, a pesquisa traz uma noção dos principais problemas enfrentados pela democracia atualmente e os fatores que, segundo o garantismo, denotam uma crise democrática, para na sequência, evidenciar qual a importância e a função da ordem democrática nas sociedades atuais, para então, a partir destas compreensões, refletir sobre as possibilidades de reorientação do modelo democrático atual, com uma aposta em um arquétipo participativo e pluralista, que privilegie a participação popular, transcendendo assim a democracia representativa clássica. O método utilizado na abordagem foi o método indutivo. O método de procedimento foi o monográfico. A técnica de pesquisa utilizada foi a pesquisa bibliográfica de fontes secundárias. A revisão bibliográfica foi compilada em obras doutrinárias.

Palavras-chave: Crise. Democracia. Democracia Participativa. Garantismo. Transnacionalidade.

\begin{abstract}
This article gives a brief overview on the contemporary democracy crisis and its relation to the phenomenon of transnationality, with the purpose to offer a summary view, but clear, of the main factors making the classical democracy insufficient to provide suitable responses to the new challenges posed by the 21 st Century global society. For this purpose, the research leads to the notion of the major issues confronting democracy currently whose factors, according to the guarantism, show a democratic crisis, as a result, to identify the importance of democratic order and its function in today's societies, and then from these understandings to think over the possibilities of the current democratic model reorientation through a participatory and participative archetype, focusing on a popular participation, transcending the classic representative democracy. The approach used was inductive method. The procedures were monographic method. The research technique used was bibliographic from secondary sources. The bibliographic review was compiled on text books.
\end{abstract}

Keywords: Crisis. Democracy. Participatory Democracy. Guarantism. Transnationality.

Artigo recebido em 29 abr. 2016 e aprovado em 5 maio 2016. 


\section{Introdução}

O presente estudo tem por finalidade demonstrar a existência de uma crise na democracia contemporânea, externando os principais fatores que deram azo a tal colapso democrático, para, a partir de então, discutir qual a finalidade da democracia nos dias atuais e quais os caminhos a adotar para a implementação de tal ideário.

Para tanto, principia-se externando a importância da democracia na promoção do pleno desenvolvimento da sociedade ${ }^{1}$ e seus indivíduos; em sequência denota os principais fatores que indicam que a democracia atual passa por uma crise (dentre eles, o fenômeno da transnacionalidade com a consequente erosão das fronteiras dos Estados) e a flagrante rapidez com que o capital e as pessoas conseguem movimentar-se pelo globo, fatores esses que conjugados a outros concedem às forças do mercado capitalista um poder e uma influência contra os quais a democracia representativa clássica não consegue fazer frente, de forma que os valores do mercado acabam por preponderar sobre os valores democráticos.

Na sequência, discute-se qual é a função da democracia no século XXI, ou seja, se ela tem a função de mera conservação do Estado (autopoiese) - sendo este um fim em si próprio, ou se ela é um instrumento que se presta a realizar certos fins idealizados pela sociedade (heteropoiese) - sendo o Estado erigido a partir da ordem democrática a uma ferramenta para a edificação de tais valores.

Após, tendo-se em mira que o Estado que se deseja é do tipo heteropoiético, com apoio na doutrina do garantismo jurídico, divide-se a democracia em dois grandes grupos (democracia formal e democracia substancial): um destinado a reunir os regimes ditos democráticos, cujo respeito aos procedimentos estatuídos é suficiente para introduzir regras no ordenamento, independente de seu conteúdo; e o outro grupo de regimes que, além do respeito às formas, também se preocupa com a

\footnotetext{
1 “"...] se a Categoria ESTADO merece ser grafada com a letra E maiúscula, muito mais merece a Categoria SOCIEDADE ser grafada com a letra E em maiúscula, porque, afinal, a SOCIEDADE é a criadora e mantenedora do Estado! Por coerência, pois, se a criatura/mantida (Estado) vem grafada com E maiúsculo, também e principalmente a criadora/mantenedora (Sociedade) deve ser grafada com o S maiúsculo!”. Conforme PASOLD, Cesar Luiz. Metodologia da Pesquisa Jurídica: Teoria e Prática. 12 ed. rev. São Paulo: Conceito Editorial, 2011. p. 169. (destaques no original).
} 
coerência dos conteúdos normativos com valores da sociedade, os quais são a sua razão de ser.

Ao final, visando as premissas anteriormente delineadas, procura-se esboçar uma proposta de caminho para a reorientação da democracia no século XXI, a fim de que ela possa ajustar-se à estrutura cada vez mais complexa, veloz e mutável da sociedade transnacional atual, de forma que novamente corresponda aos anseios sociais.

Nesse desiderato, aposta-se num modelo democrático participativo, que possa romper o paradigma da simples democracia representativa, a qual nos dias de hoje, além de não representar adequadamente as aspirações dos habitantes de uma dada coletividade, também não consegue fazer freio aos interesses do capital, que muitas vezes acaba preponderando sobre o bem comum.

Tal modelo participativo de democracia (pluralismo democrático), seria então uma forma de envolver no debate democrático não só aqueles legitimados pelo sufrágio, mas também outros setores da sociedade, dando voz e vez a outros nichos sociais que nem sempre têm oportunidade de externar seu pensamento, a fim de que todos, em conjunto, possam então discutir e afinar seus pontos de vista, de maneira a se extrair um consenso mais real e justo sobre o que é bom ou ruim para a sociedade no século XXI.

\section{A crise da democracia contemporânea e a transnacio- nalidade}

A democracia contemporânea ${ }^{2}$ pode ser definida de forma singela como o "[...] regime político que estabelece igualdade perante a lei, resguarda os direitos individuais e sociais e assegura o poder à maioria da Nação que se manifesta através do processo eleitoral" (MELO, 1978,

\footnotetext{
2 Aqui não serão abordadas e aprofundadas as diferentes correntes teóricas da democracia contemporânea (teoria democrática competitiva [elitista, pluralista], teoria democrática popular [participacionista, deliberacionista], etc.), posto não ser este o mote do presente estudo. Todavia, para uma visão panorâmica sobre tais correntes sugere-se a leitura do seguinte artigo: SILVA, Denilson. et. al.. Teoria democrática contemporânea: Modelo Democrático Competitivo e Modelo Democrático Popular. Em Tese. Revista Eletrônica dos Pós-Graduandos em Sociologia Política da UFSC. v. 10, n. 1. 2013. Disponível em: <https://periodicos.ufsc.br/index.php/emtese/article/view/ 1806-5023.2013v10n1p1/27243>. Acesso em: 11 jan. 2016.
} 
p. 32) ${ }^{3}$, ou seja, é o sistema de governo que procura assegurar o bem comum ${ }^{4}$ através do consenso entre os habitantes de um dado Estado ${ }^{5}$.

Tal sistema é visto por muitos como o melhor regime de governo, na medida em que outros sistemas políticos, além de não proporcionarem ambiente propício para que os homens desenvolvam plenamente o seu potencial, também reduzem significativamente o campo de ação dos indivíduos para proteger os próprios interesses e os de terceiros ${ }^{6}$, diminuindo assim, a esfera de responsabilidade do indivíduo. "Um governo democrático não basta para garantir que essas características se desenvolvam, mas é essencial." (DAHL, 2009, p. 69). ${ }^{7}$

Desta sorte, o paradigma reinante no mundo ocidental, tendo como pontos de partida a revolução francesa e a revolução americana, é o chamado Estado Constitucional Moderno, o qual tem como pilares fundamentais "a soberania assentada sobre um território, a tripartição dos poderes e a paulatina implantação da democracia representativa. (CRUZ et al., 2010, p. 56). ${ }^{8}$

3 MELO, Osvaldo Ferreira. Dicionário de direito político. Rio de Janeiro: Forense. 1978, p. 32.

4 Aristóteles, todavia, já observava que "[...] Não se deve, como costumavam fazer certas pessoas, definir simplesmente a democracia como o governo em que a maioria domina. [...]. Portanto, deve-se antes chamar de democracia o Estado que os homens livres governam [...].”. (ARISTÓTELES. A política. Tradução de Roberto Leal Ferreira. 1. ed. São Paulo: Martins Fontes, 1991. p. 94, 105 e 106. Título Original: La politique). 5 “A democracia é, sobretudo, um caminho: o da progressão para a liberdade.". (BONAVIDES, Paulo. A Constituição aberta. 2. ed. São Paulo: Malheiros, 1996. p.19.).

6 "Ao nascer, a maioria dos seres humanos possui o potencial para desenvolver várias características. Esse desenvolvimento depende de inúmeras circunstâncias, entre as quais a natureza do sistema político em que a pessoa vive. Apenas sistemas democráticos proporcionam as condições sob as quais essas características têm probabilidade de se desenvolver plenamente. Todos os outros regimes reduzem, em geral drasticamente, o campo em que os adultos podem agir para proteger os seus próprios interesses, levar em conta os interesses dos outros, assumir a responsabilidade por decisões importantes e emprenhar-se livremente com outros nas busca pela melhor decisão.". (DAHL, Robert. Sobre Democracia. Brasília: Editora Universidade de Brasília, 2009, p.69).

7 DAHL, Idem. p.69.

8 CRUZ, Paulo Márcio e BODNAR, Zenildo. A Transnacionalidade e a emergência do Direito e do Estado Transnacionais, in Direito e Transnacionalidade, Curitiba: Juruá, 2010, p. 56. 
Ocorre, todavia, que presentemente tais pilares restam abalados pelo que se convencionou chamar de transnacionalização ${ }^{9}$, fenômeno pelo qual, por meio da hegemonia do modelo capitalista, e a sucessiva intensificação o comércio internacional, operou-se certa desterritorialização das fronteiras, com um consequente abrandamento da soberania Estatal ${ }^{10}$, o que fez surgir, à margem das legislações internas de cada Estado, um outro tipo de ordenamento jurídico (lex mercatória, soft law, etc.) ${ }^{11}$, o qual não é controlado pelo monopólio estatal nem tão pouco respeita as fronteiras. ${ }^{12}$

Tal realidade fez com que os Estados-Nação perdessem "[...] boa parte de sua soberania, abalada pela dinâmica dos fluxos globais e das redes de riqueza, informação e poder transorganizacionais."(CASTELLS, 1999, p. 401). ${ }^{13}$, o que acaba por redundar numa espécie de crise de legitimidade, pois com tal quadro os Estados não conseguem mais dar conta dos seus compromissos sociais, em razão da preeminência dos

9 “'...] transnacional é concebido como aquilo que atravessa o nacional, que perpassa o Estado, que está além da concepção soberana do Estado e, por consequência, a ausência da dicotomia público e privado [...].”. (STELZER, Joana. O fenômeno da Transnacionalidade da dimensão jurídica. in: CRUZ, Paulo Márcio. Direito e Transnacionalidade. Curitiba: Juruá, 2011, p. 21.).

10 "Enquanto globalização remete à ideia de conjunto, de globo, enfim, o mundo sintetizado como único; transnacionalização está atada à referência do Estado permeável, mas tem na figura estatal a referência do ente em declínio. (STELZER, Idem, p. 21).

11 "Seu núcleo continua sendo a sociedade internacional de Estados soberanos, pluralisticamente segmentada, que cria direito internacional (via costumes e tratados) baseados no consentimento. Sobrepostos a isto há regimes jurídicos e políticos e IGGs [Instituições de Governança Global] dos subsistemas globais da sociedade mundial que são funcionalmente diferenciadas, e cujas estruturas institucionais, órgãos decisórios, e regras obrigatórias têm adquirido uma autonomia expressiva com relação aos seus Estados-membros e com relação uns aos outros." (COHEN, Jean. Globalization and sovereignty: rethinking legality, legitmacy and constitutionalism. Cambridge: Cambridge University Press, 2012. p. 311).

12 STELZER, Idem, p. 16.

13 CASTELLS, Manuel. O poder da identidade. São Paulo: Paz e Terra, 1999, p. 401. 
entes capitalistas privados sobre os interesses estatais ${ }^{14}$, os quais sempre que podem tentam movimentar o poder estatal em benefício próprio ${ }^{15}$.

Destarte, tem-se então que "o conceito de "bem comum" ou de "interesse da maioria" está sendo esquecido e hoje prevalecem os interesses particulares, parciais" ${ }^{16}$, pois o capitalismo formou uma tecnoestrutura que está baseada em um sistema mundial assentado sobre cinco monopólios (o monopólio das finanças, o tecnológico, o energético, o da comunicação e o monopólio militar); desta forma, o Poder Público não consegue "atuar para impedir que esta tecnoestrutura mundial concentre riqueza e ameace a própria vida no planeta.” (FERRER et. al., 2008 , p. 13). ${ }^{17}$

Neste cenário, a atual democracia contemporânea não mais se presta a proteger o indivíduo da opressão, mas apresenta-se como "um instrumento de legitimação das injustiças sociais, assim como eram aqueles instrumentos presentes no Estado Absoluto e no Estado Feudal.’."${ }^{18}$

Notável, portanto, que a transnacionalização tem como força motriz principal o comércio internacional, o qual, como já dito, sempre busca privilegiar os próprios interesses, mesmo que isso signifique sacrificar o bem comum ${ }^{19}$; nesta paisagem, a democracia é reduzida a mero

14 "Um componente essencial dessa crise de legitimidade consiste na incapacidade de o Estado cumprir com seus compromissos como Estado do bem-estar social, dada a integração da produção e do consumo em um sistema globalmente interdependente, e os respectivos processos de reestruturação do capitalismo.” (CASTELLS, Idem, p. 401) 15 "Por mais de um século, aqueles a quem Adam Smith chamou "os principais arquitetos da política" - em seus dias, os "mercadores e manufatureiros" da Inglaterra e, em nossos, seus herdeiros - procuraram refrear a democracia e os direitos humanos, desprezando mercados, exceto quando eles concediam vantagens. Como nos dias de Smith, eles naturalmente tentam mobilizar o poder do Estado para assegurar que seus próprios interesses "são mais atendidos", embora sejam revoltantes.". (CHOMSKY, Noam. Os Caminhos do Poder. Reflexões sobre a natureza humana e a desordem social. Trad. Elisabete Lacerda. Porto Alegre: Artes Médicas Sul, 1996. p. 73).

16 CRUZ, Paulo Márcio. Repensar a democracia. Revista Jurídica - CCJ/FURB, ISSN 1982-4858 v. 13, no 25, jan./jul. 2009, p. 17.

17 FERRER, Gabriel Real. CRUZ, Paulo Márcio. A crise financeira mundial, o estado e a democracia econômica. Revista Novos Estudos Jurídicos - NEJ. Vol. 13. n. 2. jul-dez 2008, p. 13.

18 CRUZ, Idem, p. 06.

19 “A globalização está se convertendo na essência de um novo Direito Econômico Internacional, o qual suprime a participação democrática em benefício de um desca- 
legitimador dos desejos do mercado internacional, o que asfixia as potencialidades mais nobres que tal sistema poderia engendrar na sociedade ${ }^{20}$.

Destaque-se ainda que mesmo naquelas questões nas quais as decisões são tomadas diretamente pelos indivíduos (democracia direta), o controle democrático exercido por estes é também bastante reduzido, pois não se pode olvidar que o sistema capitalista (que controla a mídia e a política) manipula as massas ${ }^{21}$ para que as suas decisões sejam aquelas que melhor atendam aos seus velados interesses ${ }^{22}$.

Dessarte, tem-se então que "hoje nos encontramos frente a uma verdadeira crise das formas tradicionais da Democracia Representativa, que pode traduzir-se (ou que já se traduz) na rejeição das instituições por

rado decisionismo tecnocrático." (CRUZ, Paulo Márcio. FERRER, Gabriel Real. Os novos cenários transnacionais e a democracia assimétrica. Revista de Estudos Constitucionais, Hermenêutica e Teoria do Direito (RECHTD), 2(2):96-111. jul.-dez. 2010, p. 100).

20 "Reduzindo-se a legitimação da Democracia à "tecnocracia do tipo médio", como ocorre nos Estados Unidos, estar-se-á cortando seus suprimentos mais vitais e também as potencialidades de suas diversas iniciativas." (CRUZ, Paulo Márcio. FERRER, Gabriel Real. Idem, p. 104).

21 " [...] devemos ser cautelosos ao ceder a legitimidade da democracia para sistemas não democráticos. No decurso deste século, nós já testemunhamos muitas tentativas de encobrir sistemas não democráticos no manto da democracia. [...] Todos estes foram na verdade formas não democráticas de regimes burocráticos, hierárquicos ou autoritários. Se as organizações internacionais não são democráticas, não somos obrigados a falar a verdade sobre elas?". (DAHL, Robert. Can international organizations be democratic? A skeptic view. In: SHAPIRO, I. HACKER CORDÓN, C. (Ed.). Democracy's Edges. Cambridge: Cambridge University Press, 1999. p. 33-34).

22 "La segunda consecuencia importante de esa organización de la sociedad es que el ámbito de las decisiones sujetas, en teoría, al menos, al control democrático popular es muy reducido. [...] Y la tercera consecuencia importante es que, incluso dentro del reducido ámbito de las cuestiones que se hallan sometidas, en principio, a la toma de decisiones democrática, los centros privados de poder pueden ejercer, como bien sabermos, una influencia desproporcionadamente grande utilizando métodos que resultan obvios, como el control de los medios de comunicación o de las organizaciones políticas [...] En el mejor de los casos el sistema democrático tiene un ámbito de actuación muy reducido en la democracia capitalista, e incluso dentro de ese ámbito tan reducido su funcionamiento e se ve tremendamente obstaculizado por las concentraciones de poder privado y por las maneras de pensar autoritarias y pasivas que inducen a adoptar las instituciones autocráticas, como las industrias. [...]" (Chomsky, Noam. El gobierno en el futuro. 2. ed. Tradução Francesc Roca. Barcelona: Editorial Anagrama, 2010, p. 48/50).

Resenha Eleitoral (Florianópolis), v. 20, n. 1, p. p. 9-37, jul. 2016 
parte dos cidadãos" ${ }^{23}$, fato esse que urgentemente clama por uma reflexão sobre o atual cenário mundial e sobre as qualidades que o sistema democrático contemporâneo deve ter, a fim de superar o atual modelo de concentração de riquezas e exclusão social ${ }^{24}$.

É inegável que a democracia contemporânea teve o grande mérito de livrar várias nações de sistemas autocráticos, substituindo-os por mandatários eleitos, todavia, tal transição não conclui a tarefa democrática $^{25}$, a qual precisa ser relegitimada através de uma reorientação ${ }^{26}$ que possa dar conta de mediar os conflitos entre os interesses do capital internacional e os anseios sociais, para que consiga, de fato, um "upgrade civilizatório", pois "as últimas gerações humanas são devedoras de um efetivo novo avanço do que se pode chamar de um mundo solidário e humanizado.”(FERRER et al, 2010, p.12). ${ }^{27}$

\section{Os fatores que também denotam a crise da democracia contemporânea segundo o garantismo jurídico}

O termo garantismo pode ter muitas acepções, mas o sentido corrente $^{28}$ da expressão garantismo é aquele cunhado pelo jusfilósofo Luigi Ferrajoli ${ }^{29}$, professor da universidade de Roma III, na Itália, mais

${ }^{23}$ CRUZ, Idem idem, p. 19.

${ }^{24}$ CRUZ, Idem, p. 06.

25 A "transição de regimes autoritários para governos eleitos democraticamente não encerra a tarefa da construção democrática." (STRECK, Lênio Luiz. MORAIS, José Luis Bolzan. Ciência política e teoria geral do estado. 4. ed. Porto Alegre: Livraria do Advogado, 2004, p. 114).

26 " [...] a teoria da Democracia não tem de ser necessariamente reinventada, mas certamente tem de ser re-orientada [...] "(CRUZ, Bis idem, idem, p. 05).

${ }^{27}$ FERRER, Gabriel Real. CRUZ, Paulo Márcio. Idem, p. 12.

${ }^{28}$ TRINDADE, André Karam. Revisitando o garantismo de Luigi Ferrajoli: uma discussão sobre metateoria, teoria do direito e filosofia política. Revista Eletrônica da Faculdade de Direito de Franca, Franca, v. 5, n. 1, 2012, ISSN: 1983-4225, p. 03/04.

${ }^{29}$ LUCIA, Paolo Di. Para uma completa nota bibliográfica sobre a vida e as obras de Luigi Ferrajoli vide a seguinte obra: Assiomatica del Normativo. Filosofia Critica del Diritto in Luigi Ferrajoli. LED Edizioni Universitarie di Lettere Economia Diritto, p. 318-2011, ISBN 978-88-7916-464-1.

Resenha Eleitoral (Florianópolis), v. 20, n. 1, p. 9-37, jul. 2016 
precisamente a partir da publicação da obra Diritto e ragione: teoria del garantismo penale ${ }^{30}$, em 1989.

Na aludida obra, e convergindo com o até então esposado, o autor também chama a atenção para três fatores que, até nas nações de mais avançada democracia, denotam uma crise crescente vivida pelo direito (a crise de legalidade, a inadequação estrutural das formas do Estado de Direito às funções do Welfare State e a crise do Estado Social, manifestada pelo deslocamento dos lugares de soberania) ${ }^{31}$.

Segundo Ferrajoli (1997), o primeiro aspecto que evidencia a assinalada crise é o colapso da legalidade, posto que o valor vinculativo das regras pelos ocupantes dos poderes públicos é cada vez menor, descambando, inelutavelmente, em ilegalidades, ou seja, na "na progressiva erosão do valor das regras do jogo institucional e do conjunto dos limites e dos vínculos por elas impostos ao exercício do poder público.”(FERRAJOLI, 1997, p. 89). ${ }^{32}$

Já o segundo aspecto da crise, diz respeito à inadequação estrutural das formas do Estado de Direito às funções do Welfare State, ou seja, com a crise do Estado Social, no qual o poder público, além de impor uma série de limites e de proibições, a fim de salvaguardar os direitos e liberdades dos cidadãos (Estado de Direito clássico), também precisa satisfazer os chamados direitos sociais mediante prestações positivas (estas geralmente discricionárias ou eventuais), abre-se margem para a desigualdade e a seletividade, eis que a abstração da lei perde espaço frente a "leis-providência" e a legislações avulsas ${ }^{33}$, as quais sob

30 FERRAJOLI, Luigi. Diritto e ragione. Teoria del garantismo penale. Roma-Bari: Laterza, 2004.

31 FERRAJOLI, Luigi. In: OLIVEIRA Jr., José Alcebíades, MORATO LEITE, José Rubens (org.). O novo em direito e política. Porto Alegre: Livraria do Advogado, 1997, p. $89 / 90$.

32 FERRAJOLI, Idem, p. 89.

33 Tal desestabilização das leis também é denunciado por DELMAS-MARTY: “As leis já não são feitas para durar; se mudam as condições sociais, cumprirá mudar a lei; o direito social é um direito do qual cada enunciado contém o principio de sua própria reforma; um direito obsolescente [...] Concepção que põe o direito em interação permanente com o meio social [...].”. (DELMAS-MARTY, Mireille. Por um Direito Comum; tradução Maria Ermantina de Almeida Prado Galvão. - São Paulo: Martins Fontes, 2004. - (Justiça e Direito), p. 62). 
o pretexto de tutelarem situações emergenciais acabam tornando-se um ambiente propenso a corrupção e ao arbítrio.

O terceiro fator da crise do direito é a transposição dos lugares de soberania, o que no sentir de Ferrajoli enfraquece o constitucionalismo. Tal transposição, como articulado precedentemente, dá-se devido ao fato que, com a crescente integração mundial, os espaços de decisão acabam transferindo-se para fora dos Estados nacionais ${ }^{34}$, de maneira que outras fontes de autoridade acabam por ditar as regras que antes eram monopólio da lei. Retirar da lei o monopólio [...] de geração do direito fortalece inevitavelmente a variabilidade das fontes. Não é de espantar, portanto, que a desestabilização do tempo normativo acompanhe o aparecimento e o desenvolvimento de fontes não legislativas. ${ }^{35}$

Esse paradigma ${ }^{36}$, que também está ligado à crise do Estado Social, no qual fontes normativas nascem sem grandes vinculações com os regramentos constitucionais, acaba por desprestigiar o constitucionalismo ${ }^{37}$, pondo assim em cheque a força normativa da constituição ${ }^{38}$.

Em suma, segundo o jusfilósofo italiano ${ }^{39}$, essa tríade perniciosa ao direito pode tornar-se uma crise da democracia, pois em um cenário

${ }^{34}$ Adota-se como conceito operacional de Estado, o proposto por Dallari, como sendo uma "ordem jurídica soberana, que tem por fim o bem comum de um povo situado em determinado território". (DALLARI, Dalmo de Abreu. O futuro do Estado. São Paulo: Saraiva, 2001, p. 49).

35 DELMAS-MARTY, Mireille. Por um Direito Comum; tradução Maria Ermantina de Almeida Prado Galvão. São Paulo: Martins Fontes, 2004. (Justiça e Direito), p. 71.

${ }^{36}$ Como conceito operacional da categoria 'paradigma' se adotará a seguinte definição: "É a representação de um padrão a ser seguido. Para Thomas Kuhn, as realizações científicas que geram modelos que, por período mais ou menos longo e de modo mais ou menos explícito, orientam o desenvolvimento posterior das pesquisas exclusivamente na busca da solução para os problemas por elas suscitados. É aquilo que os membros de uma comunidade partilham e, inversamente, uma comunidade científica consiste em indivíduos que partilham um paradigma.". (JAPIASSÚ, Hilton; MARCONDES, Danilo. Dicionário Básico de Filosofia. 4. ed. atual., Rio de Janeiro: Jorge Zahar, 2006, p. 211).

37 MENDES, Gilmar Ferreira. COELHO, Inocêncio Mártires, BRANCO, Paulo Gustavo Gonet. Curso de direito constitucional. 4. ed. rev. e atual. São Paulo: Saraiva, 2009, p. 88 .

38 STRECK, Lenio Luiz. Caderno de Direito Constitucional. Teoria da Constituição e Jurisdição Constitucional. Porto Alegre: Emagis, 2006, p. 05.

39 Tais fatores da crise do direito também são repisados por Ferrajoli em Principia Iuris: "Hoy en día, como veremos, estos presupuestos han cambiado em gran parte: por la 
no qual o poder público não mais se subsumi à lei, tem-se um terreno fértil para o crescimento do que Ferrajoli chamou de "formas neoabsolutistas de poder público, isentas de limites e de controles e governadas por interesses fortes e ocultos"( FERRAJOLI, 1997, p. 91) ${ }^{40}$.

Nesta paisagem, na qual o ordenamento jurídico já não é freio para os interesses de terceiros (dentre eles o mercado internacional), onde as garantias dos direitos fundamentais (de liberdade e sociais) restam sensivelmente fragilizadas, ou seja, em um cenário em que as decisões oriundas do seio da democracia representativa parecem carecer de legitimidade, resta bem delineada a necessidade de reorientação do modelo democrático atual, a fim de que o mesmo possa incorporar valores verdadeiramente democráticos ${ }^{41}$.

\section{Autopoiese e heteropoiese, a democracia como constru- ção social}

A expressão autopoiese [da expressão é grega: autós (por si próprio) e poiesis (criação, produção).] surgiu originalmente no campo da biologia, nos anos 70, nos trabalhos dos biólogos chilenos Humberto Maturana e Francisco Garcia (1997) ${ }^{42}$, que utilizaram o referido termo para assinalar os elementos distintivos de um sistema vivo e sua estrutu-

ruptura del viejo nexo entre derecho y Estado, que ha resquebrajado la unidad e incrementado la incoherencia y la falta de plenitud de los sistemas y subsistemas jurídicos; por la expansión de los asuntos y materias en los que eI derecho interviene o es llamado a intervenir, con razón o sin ella; por eI desarrollo de nuevas desigualdades personales de tipo no sólo económico o social, sino también político, ligadas a las diferentes nacionalidades y ciudadanías; por la crisis simultânea de la razón jurídica y política y de la capacidad regulativa del dereçho, frente aI crecimiento de poderes salvajes extraestatales que escapan a su control y reivindican su carácter no sujeto a regIas. Sin embargo no ha desaparecido sino que ha aumentado la necesidad de un espacio autónomo para la teoría, como lugar de replanteamiento y redefinición de las categorías jurídicas, a la altura de las nuevas formas del poder y de las nuevas funciones del derecho." (FERRAJOLI, Luigi. Principia iuris. Teoría del derecho y de la democracia. 1. Teoría del derecho, 2011, p. 04).

${ }^{40}$ FERRAJOLI, Idem idem, p. 91.

${ }^{41}$ CRUZ, Bis in idem, p. 17.

42 ROMESÍN, Humberto Maturana. GARCIA, Francisco J. Varela. De máquinas e seres vivos. 3. ed. Porto Alegre: Artes Médicas, 1997, p. 15-16.

Resenha Eleitoral (Florianópolis), v. 20, n. 1, p. p. 9-37, jul. 2016 
ra, o qual, segundo eles, é autorreprodutiva e autorreferencial ${ }^{43}$, posto que sua ordem interna é fruto da interação dos seus próprios elementos.

Tal categoria ${ }^{44}$, por sua vez, foi importada para o léxico das ciências sociais pelo sociólogo alemão Niklas Luhmann, que utilizou o termo para defender a tese de que o direito retira sua validade de si próprio (autorreferência), e não de seu exterior. (TEUBNER, 1989, p. 2). ${ }^{45}$

Ferrajoli (2002), por sua vez, também empresta o termo autopoiese para discutir a dualidade entre as doutrinas que teorizam a função do Estado como fim em si mesmo, e as que defendem ser o Estado um instrumento para a consecução de determinados fins (garantir os direitos fundamentais no caso do garantismo) ${ }^{46}$.

Assim, são autopoiéticas as doutrinas que entendem que o Estado é um fim em si próprio (AGUILERA et al., 2011) ${ }^{47}$, ou seja, que veem o Estado como uma instituição que tem o direito como meio de reforçamento e conservação. Nessas doutrinas o ordenamento jurídico é visto como instrumento a serviço da conservação Estado, no qual direitos e indivíduos são subordinados ao fim último que é a conservação do Estado.

Já em uma visão heteropoiética, o Estado não é visto como um fim a ser perseguido, mas tido como um instrumento, um meio para a consecução de certos fins idealizados pela ordem constitucional, ou seja,

${ }^{43}$ RIBEIRO, Luiz Felipe Brandini. Uma introdução ao modelo de análise da evolução da paisagem: A AUTOPOIESE GEOMORFOLÓGICA. Caminhos de Geografia. Uberlândia v. 10, n. 30 Jun/2009. ISSN 1678-6343, p. 183.

44 CAMPILONGO, Celso Fernandes. Direito e democracia. 2. ed. São Paulo: Max Limonad, 2000, p. 73.

45 TEUBNER, Gunther. O Direito como Sistema Autopoiético. Lisboa: Fundação Calouste Gulbenkian, 1989, p. 2.

46 FERRAJOLI, Luigi. Direito e razão: teoria do garantismo penal. São Paulo: Editora Revista dos Tribunais, 2002. ISBN 85-203-1955-6, p. 706.

47 "Para las doctrinas autopoyéticas, el Estado es un fin y encarna valores ético-políticos de carácter suprasocial y supraindividual a cuya conservación y reforzamiento han de instrumentalizarse los derechos." (AGUILERA PORTALES, Rafael Enrique. LÓPEZ SÁNCHEZ, Rogelio. Los derechos fundamentales en la teoría jurídica garantista de Luigi Ferrajoli. In: NUEVAS PERSPECTIVAS Y DESAFÍOS EN LA PROTECCIÓN DE LOS DERECHOS HUMANOS. AGUILERA PORTALES, Rafael Enrique (coord.). Universidad Nacional autónoma de México, 2011, ISBN 9786070224898. Instituto de Investigaciones Jurídicas, Série Estudos Jurídicos, n. 180. Biblioteca Jurídica Virtual. Disponível em: <http://biblio.juridicas.unam.mx/libros/libro.htm?l=2977.> . Acesso em: 30 maio 2015, p. 54). 
a promoção e a preservação dos direitos e garantias constitucionais (CADEMARTORI, 2006, p. 213) ${ }^{48}$, os quais devem ser instrumentalizados pelo direito pois o direito "é concebido como um "artifício" criado pelo homem e para o homem, como seu instrumento.” (FERRAJOLI, 2002, p. 707). ${ }^{49}$

Dentro de uma visão heteropoiética de Estado, este somente se legitima na medida em que efetivamente promove e defende tais direitos e garantias (CARVALHO, 2001, p. 112) ${ }^{50}$, posto que a aludida legitimação política do Estado e do direito provém de baixo para cima (FERRAJOLI, 2002, p. 707) ${ }^{51}$ (ex parte populi (CADEMARTORI, 2006, p. 214) ${ }^{52}$ ), de fora para dentro, ou seja, a partir da sociedade.

Desta sorte, o sistema garantista defende uma justificação heteropoiética do Estado e do direito (FERRAJOLI, 2011, p. 390) ${ }^{53}$, na qual a ilegitimidade externa das instituições jurídicas dependerá eminentemente da eficácia com que os aludidos direitos fundamentais sejam cumpridos (AGUILERA, 2011) ${ }^{54}$. Tal visão heteropoiética do direito e do Estado, permite a primazia do ponto de vista crítico externo, possibilitando a análise dos "perfis de inefetividade, de invalidez, e de injustiça do direito, sem provocar os equívocos e incompreensões, ou pior ainda,

${ }^{48}$ CADEMARTORI, Sergio. Estado de direito e legitimidade. Uma abordagem garantista. 2. ed. Campinas: Millennium Editora, 2006, p. 213.

${ }^{49}$ FERRAJOLI, Luigi. Direito e razão: teoria do garantismo penal. São Paulo: Editora Revista dos Tribunais, 2002. ISBN 85-203-1955-6, p. 707.

50 CARVALHO, Salo. Pena e garantias: uma leitura do garantismo de Luigi Ferrajoli no Brasil. Rio de Janeiro: Lumen juris, 2001, p. 112.

${ }^{51}$ FERRAJOLI, Idem, p. 707.

${ }^{52}$ CADEMARTORI, Idem, p. 214.

${ }^{53}$ FERRAJOLI, Luigi. Principia iuris. Teoría del derecho y de la democracia. 2. Teoría de la democracia. 2011, p. 390.

${ }^{54}$ AGUILERA PORTALES, Rafael Enrique. LÓPEZ SÁNCHEZ, Rogelio. LOS DERECHOS FUNDAMENTALES EN LA TEORÍA JURÍDICA GARANTISTA DE LUIGI FERRAJOLI. In: NUEVAS PERSPECTIVAS Y DESAFÍOS EN LA PROTECCIÓN DE LOS DERECHOS HUMANOS. AGUILERA PORTALES, Rafael Enrique (coord.). Universidad Nacional autónoma de México, 2011, ISBN 9786070224898. Instituto de Investigaciones Jurídicas, Série Estudos Jurídicos, n. 180. Biblioteca Jurídica Virtual. Disponível em: <http://biblio.juridicas.unam.mx/libros/libro.htm?l=2977>. Acesso em: 30/05/2015, p. 55. 
as falácias ideológicas" (FERRAJOLI, 2011, p. 18) ${ }^{55}$, densificando o primado dos sujeitos constituintes (ou naturais) sobre os sujeitos artificiais por eles constituídos (dentre eles o Estado). (FERRAJOLI, 2011, p. 384$)^{56}$.

O ponto de vista externo (CARVALHO, 2001, p. 113) ${ }^{57}$ reclama, então, "a análise empírica e a crítica política e jurídica dos concretos desvios ou afastamentos de todo o sistema relativamente às suas fontes de legitimação, sejam internas ou externas" (FERRAJOLI, 2002, p. 714) ${ }^{58}$, pois a denúncia das violações das garantias constitucionais, dos privilégios e das desigualdades sociais, constitui o "motor da luta pelo direito e da transformação jurídica nos distintos níveis do ordenamento: o constitucional, o legislativo e o jurisdicional." (FERRAJOLI, 2011, p. 98/99). ${ }^{59}$

Desta forma, o sistema garantista propõe a redefinição do conceito de democracia, chamado então de 'democracia substancial' (AGUILERA, 2011) ${ }^{60}$ (ou social) (CADEMARTORI, 2006, p. 211) ${ }^{61}$, para designar aqueles sistemas políticos cuja razão social é a garantia dos direitos vitais constitucionalmente estipulados (FERRAJOLI, 2011, p.

55 FERRAJOLI, Luigi. Principia iuris. Teoría del derecho y de la democracia. 1. Teoría del derecho, 2011, p. 18.

56 FERRAJOLI, Luigi. Principia iuris. Teoría del derecho y de la democracia. 1. Teoría del derecho, 2011, p. 384.

57 CARVALHO, Salo. Pena e garantias: uma leitura do garantismo de Luigi Ferrajoli no Brasil. Rio de Janeiro: Lumen juris, 2001, p. 113.

${ }^{58}$ FERRAJOLI, Luigi. Direito e razão: teoria do garantismo penal. São Paulo: Editora Revista dos Tribunais, 2002. ISBN 85-203-1955-6, p. 714.

59 FERRAJOLI, Luigi. Principia iuris. Teoría del derecho y de la democracia. 2. Teoría de la democracia., 2011, p. 98/99.

60 AGUILERA PORTALES, Rafael Enrique. LÓPEZ SÁNCHEZ, Rogelio. LOS DERECHOS FUNDAMENTALES EN LA TEORÍA JURÍDICA GARANTISTA DE LUIGI FERRAJOLI. In: NUEVAS PERSPECTIVAS Y DESAFÍOS EN LA PROTECCIÓN DE LOS DERECHOS HUMANOS. AGUILERA PORTALES, Rafael Enrique (coord.). Universidad Nacional autónoma de México, 2011, ISBN 9786070224898. Instituto de Investigaciones Jurídicas, Série Estudos Jurídicos, n. 180. Biblioteca Jurídica Virtual. Disponível em: <http://biblio.juridicas.unam.mx/libros/libro.htm?1=2977>. Acesso em: 30 maio 2015, p. 60.

61 CADEMARTORI, Sergio. Estado de direito e legitimidade. Uma abordagem garantista. 2. ed. Campinas: Millennium Editora, 2006, p. 211. 
874) ${ }^{62}$, pois em tais sistemas políticos os vínculos substanciais impostos ao legislador infraconstitucional só podem ser os direitos fundamentais tidos como essenciais pela ordem constitucional, e os correspondentes deveres impostos aos poderes públicos ((FERRAJOLI, 2011, p. 877) ${ }^{63}$, a fim de garantir tais direitos.

Cumpre, então, à teoria do direito, a tarefa de esclarecer e reconstruir essa lógica interna, e a dogmática para a necessária empreitada de identificar as lacunas e contradições existentes no ordenamento existente (FERRAJOLI, 2011, p. 32) ${ }^{64}$, denunciando assim, as veredas ilegítimas empreendidas pela democracia representativa.

\section{Da realização dos direitos constitucionais como condi- ção de legitimidade para uma democracia que se pre- tenda substancial}

Uma verdadeira democracia não pode se contentar em somente assegurar o direito à participação política dos indivíduos (MIGLINO, 2010, p. 114) ${ }^{65}$, mas deve ir além, ou seja, deve preocupar-se também em garantir que certos direitos tidos como fundamentais não sejam tolhidos, nem mesmo pela maioria politicamente eleita.

Assim, como dito alhures, introduziu-se a "distinção entre democracia formal, que diz respeito precisamente à forma de governo, e democracia substancial, que diz respeito ao conteúdo desta forma" (BOBBIO, 1987, p. 157) ${ }^{66}$, assim "enquanto o princípio da maioria nos declara quem decide, o princípio da democracia substancial nos diz o que se deve e o que não se deve decidir" (CADEMARTORI, 2006, p. 232) ${ }^{67}$, ou seja, quais são os espaços normativos que nenhum poder es-

${ }^{62}$ FERRAJOLI, Idem idem, p. 874.

${ }^{63}$ FERRAJOLI, Bis in idem, p. 877.

${ }^{64}$ FERRAJOLI, Bis in idem idem, p. 32.

${ }^{65}$ MIGLINO, Arnaldo. A cor da democracia. São José/SC: Editora Conceito Editorial. 2010, p. 114.

${ }_{66}$ BOBBIO, Norberto. Estado, governo, sociedade; por uma teoria geral da política. tradução Marco Aurélio Nogueira. Rio de Janeiro: Paz e Terra, 1987. (Coleção Pensamento Crítico, v. 69). Tradução de: Stato, governo, società: per una teoria generale della política.), 14. ed. p. 157.

${ }^{67}$ CADEMARTORI, Sergio. Estado de direito e legitimidade. Uma abordagem garantista. 2. ed. Campinas: Millennium Editora, 2006, p. 232. 
tatal pode ferir, sob pena subverter a própria ordem democrática (esfera indecidível).

Desta maneira, por maior que seja a maioria alçada ao poder em uma dada democracia, por maior que seja a quantidade de votos que tais governantes tenham alcançado na votação que os elegeu, tal fato não os legitima a invadir os espaços normativos compreendidos na esfera do indecidível, pois a função de tal espaço é justamente proteger a minoria de eventuais tentativas de lesão de seus direitos fundamentais pela maioria. (STRECK, 2003, p. 279). ${ }^{68}$

A fim de evitar-se o menoscabo total da democracia (transformando-a simplesmente a lei do mais forte) (CADEMARTORI, 2006, p. 236) ${ }^{69}$, no qual as forças motrizes do capitalismo mundial ditam livremente as regras, se faz necessária não só uma reorientação (CRUZ, 2009 , p. 05) ${ }^{70}$ da ordem democrática atual, que possa dar conta de compatibilizar os interesses capitalistas e os anseios sociais, mas, também, uma rediscussão da questão da soberania, tendo em vista que é cada vez mais evidente que as fronteiras dos Estados não são mais obstáculos nem para o capital e nem para o fluxo de pessoas.

Nesse sentir, o paradigma do Estado Democrático de Direito resta sensivelmente fragilizado quando a fronteira da esfera do indecidível é invadida, posto que essa aguda deslegitimação da ordem democrática, acaba por desaguar no menoscabo das ações políticas (CADEMARTORI, 2006, p. 234) ${ }^{71}$, afinal, quanto mais a Constituição é vilipendiada mais ela é desacreditada, podendo-se então chegar a um ponto em que não mais traduza o significado do "pacto social" (ROUSEEAU, 1981, p. 24-25) ${ }^{72}$.

O cenário atual representa uma perigosa chaga no âmago da democracia, pois ele pode acabar por ser o catalisador de processos que

68 STRECK, Lenio Luiz. Jurisdição Constitucional e Hermenêutica: Perspectivas e Possibilidades de Concretização dos Direitos Fundamentais- Sociais no Brasil. Novos Estudos Jurídicos - Volume 8 - n. 2 - p. 257-301, maio/ago., 2003, p. 279.

${ }^{69}$ CADEMARTORI, Idem, 236.

70 CRUZ, Bis in idem, p. 05.

71 CADEMARTORI, Bis in idem, p. 234.

72 ROUSEEAU, Jean Jacques. Do Contrato Social e Discursos sobre a Economia Política. (traduzido por Márcio Pugliesi e Norberto de Paula Lima). São Paulo: Hemus, 1981, p. 24-25. 
levem à ruína da ordem constitucional posta, afinal, quando a população desacredita nos mandamentos mais importantes da ordem democrática ${ }^{73}$, quando os poderes constituídos agridem, sem o menor pudor, os direitos fundamentais, tem-se a paisagem ideal para que maiorias, com os mais variados interesses, tentem tirar proveito desse momento de instabilidade para se alçarem ao poder ou para tirar alguma vantagem da aludida crise democrática.

Desta feita, para que se consiga tal "upgrade civilizatório" (FERRER et al, 2008, p. 12) ${ }^{74}$, faz-se mister, então, que a democracia se relegitime não só formalmente, mas, principalmente, substancialmente, não só respeitando os direitos fundamentais, mas empenhando-se em não dificultar a sua realização (PRETEROSSI, 2008, p. 317) ${ }^{75}$, ou seja, esforçando-se em realizá-los, pois tais aspectos representam "a condição prévia de uma democracia substancial". (CADEMARTORI, 2001, p. 180). ${ }^{76}$

\section{Qual o caminho seguir para a realização do ideário de- mocrático então?}

O modelo democrático a ser perseguido é aquele do tipo heteropoiético, pois o Estado não é um fim em si próprio, mas um meio para a realização dos valores e anseios sociais, afinal "seria um enorme erro ver o Estado Constitucional Moderno como um fim em si mesmo." (CRUZ, 2009, p. 04). ${ }^{77}$

\footnotetext{
73 (hoje nos encontramos frente a uma verdadeira crise das formas tradicionais da Democracia Representativa, que pode traduzir-se (ou que já se traduz) na rejeição das instituições por parte dos cidadãos) CRUZ, Paulo Márcio. Repensar a democracia. Revista Jurídica - CCJ/FURB, ISSN 1982-4858 v. 13, no 25, jan./jul. 2009, p. 19.

${ }^{74}$ FERRER, Gabriel Real. CRUZ, Paulo Márcio. A crise financeira mundial, o estado e a democracia econômica. Revista Novos Estudos Jurídicos - NEJ. Vol. 13. n. 2. jul-dez 2008, p. 12.

75 PRETEROSSI, Geminello. Principia iuris entre normatividad y poder: SOBRE EL ESTADO CONSTITUCIONAL DE DERECHO EN LA TEORÍA DE LUIGI FERRAJOLI. Revista Doxa, Cuadernos de Filosofía del Derecho, n. 31, 2008, p. 317.

${ }^{76}$ CADEMARTORI, Luiz Henrique Urquhart. A discricionariedade administrativa no estado constitucional de direito. Curitiba: Juruá, 2001, p. 180.

77 CRUZ, Bis in idem, p. 04.
}

Resenha Eleitoral (Florianópolis), v. 20, n. 1, p. p. 9-37, jul. 2016 
Neste sentir, deve ficar claro que a democracia representativa não é suficiente para dar conta das atuais demandas sociais (MIGLINO, 2006 , p. 14) ${ }^{78}$, ou seja, o procedimento de eleição dos representantes do povo, por si só, já não garante legitimidade ao governo posto, tendo em vista que este somente se legitima "a partir do modo pelo qual ela trata as pessoas que vivem no seu território - não importa se elas são cidadãs ou titulares de direitos eleitorais ou não." (CRUZ, 2008, p. 264). ${ }^{79}$

A validez ${ }^{80}$ da ordem democrática (para usar a expressão de Ferrajoli, 2011), deve ter, portanto, um duplo viés (formal e substancial/ material), na medida em que a democracia atual além de exigir uma adequação procedimental também clama por uma colmatação substancial (CADEMARTORI, 2001, p. 155) ${ }^{81}$, consistente no respeito aos valores sociais (CRUZ, 2009, p. 19). ${ }^{82}$.

Desta forma, diante deste cenário de crise democrática, a pergunta que fica é qual deve ser a nova roupagem da ordem democrática no mundo transnacional, que seja apta a garantir a evolução da sociedade e a proteção dos direitos fundamentais?

A resposta a tal indagação, todavia, não se encontrae acabada, mas em constante formação e mutação (DIAS et al., 2009, p. 41) ${ }^{83}$, pois em tempos de transnacionalidade, no qual a informação flui a veloci-

78 “A democracia não é apenas procedimento. Antes de tudo, o mesmo princípio dialético procedimental é já um valor que pressupõe a operatividade de outros princípios: liberdade de opinião e de expressão; liberdade de obtenção de informação imparcial e correta; publicidade dos fatos que se referem à esfera pública." (MIGLINO, Arnaldo. Democracia não é apenas procedimento. Trad. Erica Hartmann. Curitiba: Juruá, 2006, p. 14.).

${ }^{79}$ CRUZ, Paulo Márcio. Democracia e pós-modernidade. Pensar, Fortaleza, v. 13, n. 2, jul./dez., 2008, p. 264.

80 “'Válido' es el acto formal cuyas formas son todas conformes con las normas formales sobre su formacion y que admite ai menos un significado coerente con todas las normas sustantivas sobre su produccion." (FERRAJOLI, Luigi. Principia iuris. Teoría del derecho y de la democracia. 1. Teoría del derecho, 2011, p. 500).

${ }^{81}$ CADEMARTORI, Idem, p. 155.

82 "E não deve ser apenas uma legitimação formal, via procedimento. A Democracia é, acima de tudo, um valor de civilização que deve ser permanentemente atualizado." (CRUZ, Paulo Márcio. Repensar a democracia. Revista Jurídica - CCJ/FURB, ISSN 1982-4858 v. 13, no 25, jan./jul., 2009, p. 19).

83 “A democracia é sempre imperfeita e inacabada, pois novos carecimentos vão sempre se colocando e novos desejos e utopias vão se desvelando." (DIAS, Maria da Graça 
dades impressionantes e o fluxo de capital e pessoas é cada vez mais rápido, a ordem democrática deve constantemente adaptar-se (CRUZ et al., 2010, p. 103) ${ }^{84}$, para acompanhar todos os foros de decisão da vida em sociedade.

Uma das respostas para a assinalada crise poderia ser a aposta no pluralismo democrático, um pluralismo que rompa a simples democracia representativa (CRUZ et al., 2010, p. 110) ${ }^{85}$, que hoje não dá mais conta de responder aos anseios sociais e fazer frente ao capitalismo global, de maneira a dar voz a outros atores sociais (além dos partidos políticos e do voto) (CRUZ, 2009, p. 18) ${ }^{86}$, os quais podem contribuir significativamente com a governabilidade democrática, dando legitimidade às decisões tomadas.

Repensar a Democracia neste momento histórico é, portanto, fazê-lo a partir de um pluralismo que possui duas vertentes: a pluralidade de atores em disputa da governabilidade mundial - rompendo o paradigma da endogenia estatal moderna - e a pluralidade de culturas que exigem que a liberdade seja vivida a serviço da inclusão social e da igualdade, ambas vividas a serviço da diferença. (CRUZ, 2009, p. 05). ${ }^{87}$

Assim, tal democracia pluralista apostaria em outras formas de participação popular, como "os referendos, as consultas populares, as

dos Santos; SILVA, Moacyr Motta da; MELO, Osvaldo Ferreira. Política Jurídica e Pós-Modernidade. Florianópolis: Conceito Editorial, 2009, p. 41).

84 "A Democracia somente pode subsistir, isto é, continuar viva, com processos permanentes de ampliação de democratização.” (CRUZ, Paulo Márcio. FERRER, Gabriel Real. Os novos cenários transnacionais e a democracia assimétrica. Revista de Estudos Constitucionais, Hermenêutica e Teoria do Direito (RECHTD), 2(2):96-111. Jul.-dez., 2010, p. 103).

85 "O monopólio do Estado Constitucional Moderno como única fonte legítima de lealdade política para seus cidadãos começa a ceder seu lugar a um conjunto de identidades políticas mais pluralistas e múltiplas." (CRUZ et al., Idem, p. 110).

86 "[...] é preciso considerar a necessidade de um aumento da pluralidade dos processos de associação e representação democráticas por outras formas de associação e por outras formas de participação além dos partidos políticos e do voto." (CRUZ, Paulo Márcio. Repensar a democracia. Revista Jurídica - CCJ/FURB, ISSN 1982-4858 v. 13, no 25, jan./jul., 2009, p. 18).

87 CRUZ, Idem, p. 05.

Resenha Eleitoral (Florianópolis), v. 20, n. 1, p. p. 9-37, jul. 2016 
assembleias de políticas públicas, as conferências de consenso, as mesas de diálogo e controvérsia, a gestão municipal participativa" (CRUZ, 2008, p. 269) ${ }^{88}$ etc., as quais seriam acopladas à já institucionalizada democracia representativa. (CRUZ et al., 2010. p. 103). ${ }^{89}$

É preciso tomar cuidado, entretanto, para que esse alargamento da participação popular seja verdadeiro, ou seja, para que as decisões tomadas nesses fóruns de discussão sejam de fato respeitadas e implementadas sob pena de que as pessoas se desencantem e abandonem o processo. Sobre o tema, Habermas (apud GASPAR, 2013) comenta que o resultado final da participação crescente em iniciativas de cidadãos nos processos democráticos, no mais das vezes, não é bom, pois as pessoas descontentes com a inefetividade em tais foros "zangam-se, protestam, desiludem-se e voltam costas à política. É uma recusa autoconsciente, uma abstenção demonstrativa." 90

Desta sorte, diante da paisagem transnacional do século XXI, a fim de se evitar o assinalado desencanto da população com a democracia participativa, faz-se mister que os Estados nacionais abram mão de parte da sua soberania ${ }^{91}$, para possibilitarem a criação e o fortalecimento de foros de discussão (nacionais e transnacionais) que não sejam controla-

${ }^{88}$ CRUZ, Paulo Márcio. Democracia e pós-modernidade. Pensar, Fortaleza, v. 13, n. 2, jul./dez. 2008, p. 269.

89 "Provavelmente, para superar os limites da Democracia Representativa, será necessário encontrar uma complementaridade com a Democracia Participativa." (CRUZ, Paulo Márcio. FERRER, Gabriel Real. Os novos cenários transnacionais e a democracia assimétrica. Revista de Estudos Constitucionais, Hermenêutica e Teoria do Direito (RECHTD), 2(2):96-111. Jul.-dez. 2010, p. 103).

90 GASPAR, Miguel. Saída para a crise da democracia é torná-la transnacional, diz Habermas. publico.pt. publicado em 29/10/2013. Disponível em: <http://www.publico. $\mathrm{pt} / \mathrm{mundo} /$ jornal/saida-para-a-crise-da-democracia-e-tornala-transnacional-diz-habermas-27318692>. Acesso em 11 jan. 2016.

91 Jürgen Habermas destaca: “O aprofundamento de uma cooperação institucionalizada exige uma transferência adicional de soberania e a consequente revisão dos tratados; as elites políticas precisariam de encontrar coragem para levantar, nas suas arenas políticas nacionais, a controvérsia inevitavelmente polarizadora sobre as estratégias alternativas, nenhuma das quais pode ser seguida sem custos" (GASPAR, Miguel. Saída para a crise da democracia é torná-la transnacional, diz Habermas. publico.pt. Publicado em 29/10/2013. Disponível em: <http://www.publico.pt/mundo/jornal/saida-para-a-crise-da-democracia-e-tornala-transnacional-diz-habermas-27318692>. Acesso em: 11 jan. 2016. 
dos por nenhum outro Estado, deitando assim, quiçá, os delineamentos de uma democracia transnacional verdadeiramente legítima.

A transnacionalização da Democracia exigirá uma limitação efetiva da soberania dos estados, mas, ao contrário do que ocorre com frequência no momento atual, essa limitação não deve e nem pode ser exercida por outros estados. [...] É urgente, portanto, a discussão sobre a possibilidade de um Direito cosmopolita e de uma Democracia capaz de regular, limitar e configurar, para além das fronteiras do Estado Constitucional Moderno, uma verdadeira nova ordem, uma verdadeira ordem global democrática de Direito, capaz de superar a atual ordem, debilitada e caduca." (CRUZ et al., 2010, p. 107). ${ }^{92}$

Torna-se imperiosa a edificação de um novo modelo de Estado, mais aberto e participativo, que poderia ser "o mediador das relações políticas, sociais e econômicas locais e regionais com aquelas globalizadas, ou mundializadas." (CRUZ, 2009, p. 04). ${ }^{93}$

Esse novo Estado, erigido sob um paradigma de democracia participativa, equilibraria não somente os poderes dos representantes eleitos, mas, também, os poderes para a sociedade organizada e para aqueles legitimados por seus conhecimentos técnico-profissionais, equalizando diversos interesses (do mercado, sociais, ambientais, etc.) ${ }^{94}$, oriundos de lugares diferentes da sociedade, o que poderia verdadeiramente expressar os anseios da sociedade (CRUZ et al., 2010, p. 103). ${ }^{95}$

92 CRUZ, Paulo Márcio. FERRER, Gabriel Real. Os novos cenários transnacionais e a democracia assimétrica. Revista de Estudos Constitucionais, Hermenêutica e Teoria do Direito (RECHTD), 2(2): jul.-dez. 2010, p. 107.

93 CRUZ, Bis in idem, p. 04.

94 "Sistema que deverá proteger simultaneamente os modelos de mercado (econômicos), os modelos sociais (social) e os modelos ambientais - tridimensionalidade da sustentabilidade. Será necessário proporcionar em âmbito, local, nacional, internacional, supranacional e principalmente transnacional, oportunidades sociais e econômicas em conjunto com o compromisso coletivo de criação de uma sociedade sustentável para toda a humanidade." (Glasenapp, Maikon Cristiano e Cruz, Paulo Márcio. GOVERNANÇA E SUSTENTABILIDADE: CONSTITUINDO NOVOS PARADIGMAS NA PÓS-MODERNIDADE. Revista Brasileira de Meio Ambiente Digital e Sociedade da Informação - RBMAD, São Paulo, volume 1, número 2, jul./dez. 2014, p.400).

95 CRUZ et al.,2010, p. 103.

Resenha Eleitoral (Florianópolis), v. 20, n. 1, p. p. 9-37, jul. 2016 
Com tais iniciativas, poder-se-ia, então, avançar de uma globalização meramente econômica, calcada no egoísmo que insiste em fazer valer a vontade do capital, doa a quem doer (CRUZ, 2009, p. 17) ${ }^{96}$, para uma globalização também política e social, calcada em valores democráticos ${ }^{97}$ aptos a promoverem uma ética de emancipação, a promover uma relação sadia entre os interesses capitalistas e os aspirações da comunidade (regional e transnacional).

\section{Considerações Finais}

Do que foi aqui articulado, resta claro que pensar na "questão democrática contemporaneamente implica inserir o debate no contexto próprio à sociedade atual" (STRECK, 2004, p. 123) ${ }^{98}$, a qual, como é sabença, é marcada flagrantemente pela erosão das fronteiras dos Estados e pela transnacionalização, conjugada ainda, pela notável mobilidade do capital e de pessoas pelo globo afora. Tal paradigma é também caracterizado pela lógica neoliberal do mercado, marcantemente egoísta e desprovido de amarras éticas, de maneira que ele não se compatibiliza com outros ideais (notadamente os democráticos) que não a maximização da riqueza.

Nesse horizonte, no qual a democracia representativa não consegue mais fazer frente aos novos desafios engendrados pela sociedade globalizada do século XXI ${ }^{99}$, na qual a ordem democrática instituída a partir das revoluções francesa e americana não se apresenta mais como uma resposta satisfatória aos problemas daí advindos (CRUZ, 2009,

\footnotetext{
${ }^{96}$ CRUZ, Bis in idem idem, p. 17.

97 "Nesse cenário em transição, a globalização do mercado e das tecnologias da informação deverá estar acompanhada de uma globalização política e social, na qual os valores democráticos tenham um claro protagonismo" (CRUZ, Paulo Márcio. Repensar a democracia. Revista Jurídica - CCJ/FURB, ISSN 1982-4858 v. 13, no 25, jan./jul. 2009, p. 05). 98 STRECK, Lênio Luiz. MORAIS, José Luis Bolzan. Ciência política e teoria geral do estado. 4. ed. Porto Alegre: Livraria do Advogado, 2004, p. 123.

99 "A democracia representativa falha na medida em que, na prática, não representa os interesses populares, mas o interesse do capital. É que o sistema político opera com o código de outro sistema, o econômico. Há uma clara subjugação do poder político pelo poder econômico." (DIAS, Maria da Graça dos Santos; SILVA, Moacyr Motta da; MELO, Osvaldo Ferreira. Política Jurídica e Pós-Modernidade. Florianópolis: Conceito Editorial, 2009, p. 12).
} 
p. 17) ${ }^{100}$ (crise de legalidade, deslocamento dos lugares de soberania, inadequação do Estado às funções do Welfare State), faz-se necessário discutir novos caminhos para a democracia, a fim de que os valores democráticos possam reorientar a vida em sociedade.

Tendo-se em mira que o Estado não é um fim em si próprio, ou seja, que a figura do Estado é tão somente um meio para a consecução de determinados objetivos da sociedade (Estado heteropoiético), tem-se então que o modelo democrático a ser perseguido é aquele dito "substancial” (AGUILERA et al., 2011, p. 60) ${ }^{101}$, aquele que é verdadeiramente comprometido com as aspirações mais preciosas de uma sociedade, as quais, no mais das vezes, vêm encartadas nos direitos e garantias constitucionais.

Para a eclosão dessa democracia substancial do século XXI (CRUZ, 2009, p. 05) ${ }^{102}$, todavia, não existe um caminho único, mas caminhos - sendas que, se bem empreendidas pelos partícipes do processo democrático, podem contribuir significativamente para a sociedade global evolua e se integre (CRUZ, 2009, p. 05) ${ }^{103}$.

100 "Espera-se que tenha ficado razoavelmente claro que as democracias representativas atuais estão carentes de uma estrutura ética concebida a partir de valores democráticos conectados com as necessidades do século XXI." (CRUZ, Paulo Márcio. Repensar a democracia. Revista Jurídica - CCJ/FURB, ISSN 1982-4858 v. 13, no 25, jan./jul., 2009, p. 17).

101 AGUILERA PORTALES, Rafael Enrique. LÓPEZ SÁNCHEZ, Rogelio. LOS DERECHOS FUNDAMENTALES EN LA TEORÍA JURÍDICA GARANTISTA DE LUIGI FERRAJOLI. In: NUEVAS PERSPECTIVAS Y DESAFÍOS EN LA PROTECCIÓN DE LOS DERECHOS HUMANOS. AGUILERA PORTALES, Rafael Enrique (coord.). Universidad Nacional autónoma de México, 2011, ISBN 9786070224898. Instituto de Investigaciones Jurídicas, Série Estudos Jurídicos, n. 180. Biblioteca Jurídica Virtual. Disponível em: <http://biblio.juridicas.unam.mx/libros/libro.htm?1=2977>. Acesso em: 30 maio 2015. P. 60

102 “[...] na configuração da nova ordem mundial, a Democracia deverá desempenhar um papel mais importante que o Estado Constitucional Moderno [...]" (CRUZ, Paulo Márcio. Repensar a democracia. Revista Jurídica - CCJ/FURB, ISSN 1982-4858 v. 13, no 25, jan./jul. 2009, p. 05).

103 "A Democracia deve servir, antes de tudo, para que a Sociedade evolua, para que a diversidade de opções políticas e não políticas (culturais, relacionais, territoriais, sindicais, étnicas, de idade etc.) possa se movimentar o mais livremente possível, enriquecendo a complexidade da comunidade." (CRUZ, Paulo Márcio. Democracia e pós-modernidade. Pensar, Fortaleza, v. 13, n. 2, jul./dez. 2008, p. 269).

Resenha Eleitoral (Florianópolis), v. 20, n. 1, p. p. 9-37, jul. 2016 
Uma das veredas que pode ser apontada é a aposta na democracia participativa, uma democracia que possa transcender a tecnicista democracia representativa, a qual atualmente carece de legitimidade, não só porque se tem o nítido sentimento que ela não representa as aspirações sociais, estando mais comprometida com outros interesses que não o bem comum, mas também porque a democracia representativa clássica não consegue dialogar eficazmente com a sociedade globalizada, pois reluta em abrir mão de seu poder/soberania, impossibilitando a criação de novos foros de discussão e decisão para questões que hoje não são somente nacionais, mas sim, transnacionais, causando dessa forma um inevitável conflito.

A opção por um modelo democrático verdadeiramente participativo poderia contribuir para a edificação de uma globalização mais fraterna e solidária, diminuindo conflitos e integrando pessoas e organizações, de maneira a criar um "novo estilo de vida, para todos, com comunhão de civilizações e não choque de civilizações, como explica Samuel Huntington." (apud CRUZ, 2009, p. 05). ${ }^{104}$

Desta forma, uma democracia participativa da forma ora proposta buscaria ir além da democracia representativa, para incluir nos processos de discussão e decisão democráticos, além dos legitimados pelo voto, a sociedade organizada e os detentores de conhecimentos técnico-profissionais ${ }^{105}$, de maneira a possibilitar que os diversos interesses envolvidos em uma dada questão (Glasenapp et al., 2014, p. 400) ${ }^{106}$ possam dialogar em condições isonômicas ${ }^{107}$, a fim de juntos encontra-

${ }^{104}$ CRUZ, Paulo Márcio. Repensar a democracia. Revista Jurídica - CCJ/FURB, ISSN 1982-4858 v. 13, no 25, jan./jul., 2009, p. 05.

105 " [...] estruturas comunicativas das quais participam atores situados em diferentes posições com a finalidade de influir nas políticas públicas, nas normas, e nos procedimentos decisórios de entidades muito poderosas, e também nas quais negociam o significado de seu próprio empreendimento. Esses atores fazem uso de padrões horizontais de comunicação e de troca que permitem uma agência que é mais do que a soma das suas partes." (COHEN, Jean. Sociedade civil e globalização: repensando categorias. Revista Dados, v. 46, n. 3, Rio de Janeiro, 2003, p. 435).

106 Glasenapp, Maikon Cristiano; Cruz, Paulo Márcio. Governança e sustentabilidade: CONSTITUINDO NOVOS PARADIGMAS NA PÓS-MODERNIDADE. Revista Brasileira de Meio Ambiente Digital e Sociedade da Informação - RBMAD, São Paulo, volume 1, número 2, jul./dez. 2014, p.400.

107 "Claro que há diferenças abissais entre indivíduos no que diz respeito à educação, experiência ou riqueza, mas isto não pode servir de justificativa para que a opinião - ou

Resenha Eleitoral (Florianópolis), v. 20, n. 1, p. 9-37, jul. 2016 
rem as melhores decisões, o que poderia verdadeiramente expressar os anseios da sociais (CRUZ et al., 2010, p. 103) ${ }^{108}$.

Nesse desiderato, será necessário pensar na criação de novas instituições transnacionais democráticas, as quais possam não só tratem de questões que interessam a mais de um Estado, mas também, envolvam o mercado ${ }^{109}$, para que seus interesses também sejam considerados e que o poder do capital seja limitado, a fim de que o mercado internacional se amolde a padrões éticos mínimos de humanidade ${ }^{110}$.

Portanto, a título de fecho e sem a pretensão de esgotar o assunto, quer em sua extensão quer em sua profundidade, finaliza-se aduzindo que a reconstrução da ordem democrática no século XXI é uma tarefa constante, que pode ser empreendida em várias frentes, dentre elas (a que se acredita ser a mais promissora) a de uma proposta democrática participativa, que promova a inclusão, com a participação de forma isonômica de todos os nichos sociais e a limitação dos poderes do mercado, buscando fomentar uma cultura de alteridade e solidariedade ${ }^{111}$.

interesses - de alguns, tenham um valor superior à de muitos." (CRUZ, Paulo Márcio. Repensar a democracia. Revista Jurídica - CCJ/FURB, ISSN 1982-4858 v. 13, no 25, jan./jul. 2009, p. 09).

108 CRUZ, Paulo Márcio. FERRER, Gabriel Real. Os novos cenários transnacionais e a democracia assimétrica. Revista de Estudos Constitucionais, Hermenêutica e Teoria do Direito (RECHTD), 2(2):96-111. Jul.-dez. 2010, p. 103.

109 "A democracia exige que processos econômicos sejam inseridos em processos sociais [...] Do contrário, os processos de mercado, livres do Estado, fazem com que a soberania dos Estados Constitucionais Modernos e a sua legitimidade democrática degenerem paulatinamente em farsa." (CRUZ, Paulo Márcio. FERRER, Gabriel Real. Os novos cenários transnacionais e a democracia assimétrica. Revista de Estudos Constitucionais, Hermenêutica e Teoria do Direito (RECHTD), 2(2): jul.-dez. 2010, p. 106). 110 "Em tal sentido, faz-se urgente a criação de novas instituições transnacionais democráticas capazes de regular e controlar com efetividade a atividade econômica e financeira dos mercados e ajudar a ajustar a padrões humanitários esse grande cassino em que se converteu o atual mercado financeiro e que produziu essa crise que ceifa empregos e esperanças." (CRUZ, Paulo Márcio. Repensar a democracia. Revista Jurídica - CCJ/FURB, ISSN 1982-4858 v. 13, no 25, jan./jul. 2009, p. 18).

111 "A nova cultura político-filosófica fundada num humanismo da alteridade servirá de paradigma para a democracia, a cidadania e os direitos humanos." (DIAS, Maria da Graça dos Santos; SILVA, Moacyr Motta da; MELO, Osvaldo Ferreira. Política Jurídica e Pós-Modernidade. Florianópolis: Conceito Editorial, 2009. p. 31). 


\section{Referências}

AGUILERA PORTALES, Rafael Enrique. LÓPEZ SÁNCHEZ, Rogelio. Los derechos fundamentales en la teoría jurídica garantista de Luigi Ferrajoli. In: nuevas perspectivas y desafíos en la protección de los derechos humanos.

AGUILERA PORTALES, Rafael Enrique (coord.). Universidad Nacional autónoma de México, 2011, ISBN 9786070224898. Instituto de Investigaciones Jurídicas, Série Estudos Jurídicos, n. 180. Biblioteca Jurídica Virtual. Disponível em: <http://biblio.juridicas.unam.mx/libros/libro.htm?l=2977>. Acesso em: 30 maio 2015.

ARISTÓTELES. A política. Tradução de Roberto Leal Ferreira. Título Original: La politique. 1. ed. São Paulo: Martins Fontes, 1991.

BOBBIO, Norberto. Estado, governo, sociedade; por uma teoria geral da política. tradução Marco Aurélio Nogueira. Rio de Janeiro: Paz e Terra, 1987. (Coleção Pensamento Crítico, v. 69). Tradução de: Stato, governo, società: per una teoria generale della política.), 14. ed.

BONAVIDES, Paulo. A Constituição aberta. 2. ed. São Paulo: Malheiros, 1996.

CADEMARTORI, Luiz Henrique Urquhart. A discricionariedade administrativa no estado constitucional de direito. Curitiba: Juruá, 2001.

CADEMARTORI, Sergio. Estado de direito e legitimidade. Uma abordagem garantista. 2. ed. Campinas: Millennium Editora, 2006.

CAMPILONGO, Celso Fernandes. Direito e democracia. 2. ed. São Paulo: Max Limonad, 2000.

CARVALHO, Salo. Pena e garantias: uma leitura do garantismo de Luigi Ferrajoli no Brasil. Rio de Janeiro: Lumen juris, 2001.

CASTELLS, Manuel. O poder da identidade. São Paulo: Paz e Terra, 1999.

CHOMSKY, Noam. El gobierno en el futuro. 2. ed. Tradução Francesc Roca. Barcelona: Editorial Anagrama, 2010.

. Os Caminhos do Poder. Reflexões sobre a natureza

humana e a desordem social. Trad. Elisabete Lacerda. Porto Alegre: Artes Médicas Sul, 1996.

COHEN, Jean. Globalization and sovereignty: rethinking legality, legitmacy and constitutionalism. Cambridge: Cambridge University Press, 2012. 
Sociedade civil e globalização: repensando categorias. Revista Dados, v. 46, n. 3, Rio de Janeiro, 2003.

CRUZ, Paulo Márcio e BODNAR, Zenildo. A Transnacionalidade e a emergência do Direito e do Estado Transnacionais, in Direito e Transnacionalidade, Curitiba: Juruá, 2010.

CRUZ, Paulo Márcio. FERRER, Gabriel Real. Os novos cenários transnacionais e a democracia assimétrica. Revista de Estudos Constitucionais, Hermenêutica e Teoria do Direito (RECHTD), 2(2):96-111. Jul./dez. 2010.

CRUZ, Paulo Márcio. Democracia e pós-modernidade. Pensar, Fortaleza, v. 13, n. 2, jul./dez. 2008.

. Direito e Transnacionalidade. Curitiba: Juruá, 2011.

. Repensar a democracia. Revista Jurídica - CCJ/

FURB, ISSN 1982-4858 v. 13, no 25, jan./jul. 2009.

DAHL, Robert. Sobre Democracia. Brasília: Editora Universidade de Brasília, 2009.

DALLARI, Dalmo de Abreu. O futuro do Estado. São Paulo: Saraiva, 2001.

DELMAS-MARTY, Mireille. Por um Direito Comum; tradução Maria Ermantina de Almeida Prado Galvão. - São Paulo: Martins Fontes, 2004. (Justiça e Direito).

DIAS, Maria da Graça dos Santos; SILVA, Moacyr Motta da; MELO, Osvaldo Ferreira. Política Jurídica e Pós-Modernidade. Florianópolis: Conceito Editorial, 2009.

FERRAJOLI, Luigi. Direito e razão: teoria do garantismo penal. São Paulo: Editora Revista dos Tribunais, (tradutores, Ana Paula Zomer, Fauzi Hassan Choukr, Juarez Tavares e Luiz Flávio Gomes) ISBN 85-203-1955-6), 2002.

ma-Bari: Laterza, 2004.

. Diritto e ragione. Teoria del garantismo penale. Ro-

. Principia iuris. Teoría del derecho y de la democra-

cia. 1. Teoría del derecho. Traducción de Perfecto Andrés Ibáñez, Carlos Bayón, Marina Gascón, Luis Prieto Sanchís y Alfonso Ruiz Miguel. Madrid: Editorial Trotta S.A., 2011.

. Principia iuris. Teoría deI derecho y de la demo-

cracia. 2. Teoría de la democracia. Traducción de Perfecto Andrés Ibáñez, Carlos Bayón, Marina Gascón, Luis Prieto Sanchís y Alfonso Ruiz Miguel. Madrid: Editorial Trotta S.A., 2011. 
FERRER, Gabriel Real; CRUZ, Paulo Márcio. A crise financeira mundial, o estado e a democracia econômica. Revista Novos Estudos Jurídicos - NEJ. Vol. 13. n. 2. jul-dez 2008.

GASPAR, Miguel. Saída para a crise da democracia é torná-la transnacional, diz Habermas. publico.pt. publicado em 29/10/2013. Disponível em: $<\mathrm{http}$ //www.publico.pt/mundo/jornal/saida-para-a-crise-da-democracia-e-tornala-transnacional-diz-habermas-27318692>, Acesso em 11/01/2016, as 09:58h.

GLASENAPP, Maikon Cristiano; CRUZ, Paulo Márcio. Governança e sustentabilidade: constituindo novos paradigmas na pós-modernidade. Revista Brasileira de Meio Ambiente Digital e Sociedade da Informação RBMAD, São Paulo, volume 1, número 2, jul./dez. 2014.

JAPIASSÚ, Hilton; MARCONDES, Danilo. Dicionário Básico de Filosofia. 4. ed. atual., Rio de Janeiro: Jorge Zahar, 2006.

LUCIA, Paolo Di. Assiomatica del Normativo. Filosofia Critica del Diritto in Luigi Ferrajoli. LED Edizioni Universitarie di Lettere Economia Diritto, ISBN 978-88-7916-464-1.

MELO, Osvaldo Ferreira. Dicionário de direito político. Rio de Janeiro: Forense. 1978.

MENDES, Gilmar Ferreira; COELHO, Inocêncio Mártires; BRANCO, Paulo Gustavo Gonet. Curso de direito constitucional. 4. ed. rev. e atual. São Paulo: Saraiva, 2009.

MIGLINO, Arnaldo. Democracia não é apenas procedimento. Trad. Erica Hartmann. Curitiba: Juruá, 2006.

Editorial. 2010.

. A Cor da Democracia. São José/SC: Editora Conceito

OLIVEIRA Jr., José Alcebíades; MORATO LEITE, José Rubens (org.). O

novo em direito e política. Porto Alegre: Livraria do Advogado, 1997.

PASOLD, Cesar Luiz. Metodologia da Pesquisa Jurídica: Teoria e Prática. 12 ed. rev. São Paulo: Conceito Editorial, 2011.

PRETEROSSI, Geminello. Principia iuris entre normatividad y poder: sobre el estado constitucional de derecho en la teoría de Luigi Ferrajoli. Revista Doxa, Cuadernos de Filosofía del Derecho, n. 31, 2008.

RIBEIRO, Luiz Felipe Brandini. Uma introdução ao modelo de análise da evolução da paisagem: a autopoiese geomorfológica. Caminhos de Geografia. Uberlândia v. 10, n. 30 Jun/2009. ISSN 1678-6343. 
ROMESÍN, Humberto Maturana; GARCIA, Francisco J. Varela. De máquinas e seres vivos. 3. ed. Porto Alegre: Artes Médicas, 1997.

ROUSEEAU, Jean Jacques. Do Contrato Social e Discursos sobre a Economia Política. (traduzido por Márcio Pugliesi e Norberto de Paula Lima). São Paulo: Hemus, 1981.

SHAPIRO, I. HACKER CORDÓN, C. (Ed.). Democracy's Edges. Cambridge: Cambridge University Press, 1999.

SILVA, Denilson. Et. All. Teoria democrática contemporânea: Modelo Democrático Competitivo e Modelo Democrático Popular. Em Tese. Revista Eletrônica dos Pós-Graduandos em Sociologia Política da UFSC. v. 10, n. 1. 2013. Disponível em: <https://periodicos.ufsc.br/index.php/emtese/article/ view/1806-5023.2013v10n1p1/27243>. Acesso em: 11 jan 2016.

STELZER, Joana. O fenômeno da transnacionalização da dimensão jurídica, in Direito e Transnacionalidade, Curitiba: Juruá, 2011.

STRECK, Lenio Luiz. Caderno de Direito Constitucional. Teoria da Constituição e Jurisdição Constitucional. Porto Alegre: Emagis, 2006.

STRECK, Lênio Luiz; MORAIS, José Luis Bolzan. Ciência política e teoria geral do estado. 4. ed. Porto Alegre: Livraria do Advogado, 2004.

STRECK, Lenio Luiz. Jurisdição Constitucional e Hermenêutica: Perspectivas e Possibilidades de Concretização dos Direitos FundamentaisSociais no Brasil. Novos Estudos Jurídicos - Volume 8 - n. 2 - p. 257-301, maio/ago. 2003.

TEUBNER, Gunther. O Direito como Sistema Autopoiético. Lisboa: Fundação Calouste Gulbenkian, 1989.

TRINDADE, André Karam. Revisitando o garantismo de Luigi Ferrajoli: uma discussão sobre metateoria, teoria do direito e filosofia política. Revista Eletrônica da Faculdade de Direito de Franca, Franca, v. 5, n. 1, 2012, ISSN: 1983-4225.

Maurizio Oliviero - Doutor em Direito Público pela Università di Roma "Tor Vergata" (Itália). Professor visitante com bolsa CAPES no Programa de Pós-Graduação Stricto Sensu em Ciência Jurídica - Cursos de Mestrado e Doutorado. Embaixador do Programa Erasmus pela Itália.

Pablo Franciano Steffen - Doutorando em Ciências Jurídicas pela UNIVALI.

Daniel Mayerle - Doutorando em Ciências Jurídicas pela UNIVALI. 